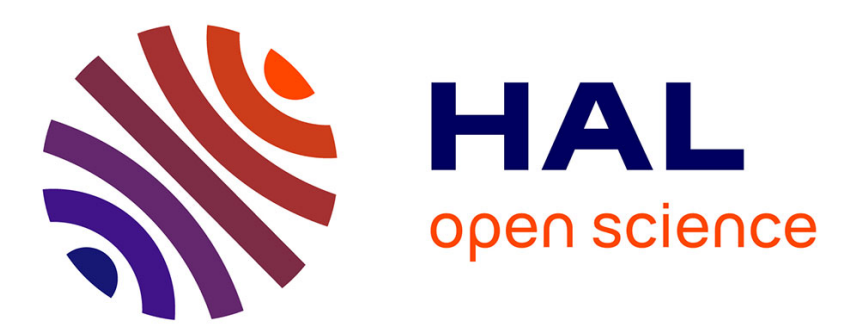

\title{
Governing Common-Property Assets: Theory and Evidence from Agriculture
}

\author{
Simon Cornée, Madeg Le Guernic, Damien Rousselière
}

\section{To cite this version:}

Simon Cornée, Madeg Le Guernic, Damien Rousselière. Governing Common-Property Assets: Theory and Evidence from Agriculture. Journal of Business Ethics, 2020, 166 (4), pp.691-710. 10.1007/s10551-020-04579-1 . hal-02922732

\section{HAL Id: hal-02922732 \\ https://hal.inrae.fr/hal-02922732}

Submitted on 23 Nov 2020

HAL is a multi-disciplinary open access archive for the deposit and dissemination of scientific research documents, whether they are published or not. The documents may come from teaching and research institutions in France or abroad, or from public or private research centers.
L'archive ouverte pluridisciplinaire HAL, est destinée au dépôt et à la diffusion de documents scientifiques de niveau recherche, publiés ou non, émanant des établissements d'enseignement et de recherche français ou étrangers, des laboratoires publics ou privés. 


\title{
Governing Common-Property Assets: Theory and Evidence from Agriculture*
}

\author{
Simon Cornée** \\ Université de Rennes 1, CREM UMR CNRS 6211, and CERMi \\ Faculté des Sciences Économiques \\ 7, place Hoche CS 86514 \\ 35065 Rennes cedex \\ France \\ simon.cornee@univ-rennes1.fr \\ Madeg Le Guernic \\ Université de Rennes 1, CNRS, CREM-UMR6211 \\ F-35000 Rennes \\ France \\ madeg.leguernic@univ-rennes1.fr \\ Damien Rousselière \\ Agrocampus Ouest, UMR Smart-Lereco \\ CRISES, Université du Québec à Montréal \\ 2, rue André le Nôtre \\ F-49045 ANGERS Cedex \\ France \\ damien.rousseliere@agrocampus-ouest.fr
}

This version May 2020

(Accepted for publication in Journal of Business Ethics)

Keywords: Governance of the Commons; Farm Machinery Sharing Cooperative Arrangements; Ethical Aspects.

JEL Codes: G3, M00 ; O17, P32, Q13.

\footnotetext{
* The authors are grateful to the special issue guest editors and to two anonymous reviewers as well as to Carlo Borzaga, Murray Fulton, Franck Thomas, Peter Wirtz, and numerous conference and seminar participants for their helpful comments and discussions. In addition, we would like to make special reference to Georgeanne Artz (Iowa State University), who worked on farm machinery CPAs and who has recently passed away.

$* *$ Corresponding author.
} 


\title{
Governing Common-Property Assets: Theory and Evidence from Agriculture
}

\begin{abstract}
This paper introduces a refined approach to conceptualising the commons in order to shed new light on cooperative practices. Specifically, it proposes the novel concept of Common-Property Assets (CPAs). CPAs are exclusively human-made resources owned under common-property ownership regimes. Our CPA model combines quantity (the flow of resource units available to members) and quality (the impact produced on the community by the members' appropriation of the resource flow). While these two dimensions are largely pre-existing in the conventional case of natural common-pool resources, they directly depend on members' collective action in CPAs. We apply this theoretical framework to farm machinery sharing agreements-a widespread grassroots cooperative phenomenon in agriculture - using a systematic literature review to generalise the findings from a sample of 54 studies published from 1950 to 2018. Our findings show that in successful CPAs, members endorse and do not deviate from a quantityquality equilibrium that is collectively agreed upon. Despite the existence of thresholds for both quantity and quality due to (axiological) membership heterogeneity, qualitative changes in respect of the common good are possible in CPAs that promote democratic practices. Our study has potentially strong implications for developing ethics in cooperatives and the sustainable development of communities worldwide.
\end{abstract}




\section{Introduction}

Cooperatives have a long history as key players in the socioeconomic development of communities worldwide (Stiglitz 2009). As democratic organisations managed by their members, cooperatives are distinguished from investor-owned corporations by their orientation towards broader social goals. However, despite their economic significance in agriculture, banking, insurance, and healthcare, cooperatives have been largely ignored in the recent literature (Kalmi 2007). The commons paradigm offers a promising opportunity to reconceptualise cooperative practices and more specifically their governance. The theories of the commons challenge the primacy of the private property paradigm and address the necessity of investigating alternative ways of conducting economic activities and their ethical consequences (Peredo and McLean 2019; Périlleux and Nyssens 2017).

While there is evidence of commons experiences from time immemorial (Dardot and Laval 2014; Polanyi 1944), the recent surge of academic interest in the commons, especially in the fields of business and economics, owes a great deal to Ostrom's influential work. In particular, she refutes Hardin's (1968) contention that natural common-pool resources (CPRs) (e.g. water, grassland, fishing resources) are doomed to exhaustion by identifying the key institutional arrangements that allow for their sustainable management (Ostrom 1990). The scope of the CPR framework has since been considerably broadened to re-conceptualise shared resources and now embraces a variety of 'new commons' encompassing all types of fields, any combination of property rights, and natural as well as human-made resources (Hess 2008). This framework is quite accommodating, given the commons continuum has too many distinctive features for it to be captured in a universal set of principles (Bollier 2011). In this paper, we argue that a more bounded conceptualisation of the commons is needed to shed new light on the cooperative realm. We therefore propose the novel category of common-property assets 
(CPAs), which delimits the commons approach in two respects. First, CPAs are exclusively commons that are created by people through collective action, in other words, they are humanmade resources. Second, to account for the legal status of cooperatives, we postulate that CPAs have an exclusive property regime (common property).

A major contribution of our approach is that by adapting CPR theory to CPAs, we are able to understand the governance of cooperatives from the perspective of generating - as opposed to conserving - a specific flow of resource units. In the wake of Ostrom's work, the existing institutionalist framework on the management of CPRs has mainly focused on establishing a set of institutional arrangements (i.e. rules and norms) that lead to sustainable withdrawal rates to ensure the renewal of a pre-existing (natural) resource stock. In CPAs, the resource stock does not pre-exist but varies as a function of the cooperation level among members. Consequently, CPA members can increase the quantity (i.e. the flow of resource units available to them) not only by modifying the institutional arrangements regulating the withdrawal rate (as in CPRs) but also by expanding the size of the resource stock (unlike in CPRs). Moreover, focusing only on the quantity of a commons leaves open the question of whether and, subsequently, to what extent the members' appropriation of the resource flow produces a positive impact on themselves and their community. This quality dimension is especially crucial in CPAs (with respect to CPRs) because it is determined both by the way commoners use and appropriate the resource flow (as in CPRs) and by the substance or nature of the resource stock (unlike in CPRs), which has to be collectively agreed by CPA members.

The combining of quantity and quality in our CPA model expands the institutionalist perspective of commons governance by also taking into consideration the ethics perspective. Regarding quantity, the members' propensity to cooperate does not rely solely on institutional arrangements but is also firmly rooted in an ethical fabric. More importantly, the quality 
dimension clearly addresses the moral question of how the human action of creating and maintaining a CPA helps members and their community to secure a better life (Greenwood and Freeman 2017). This refers in particular to the ethics of the common good, which is concerned with how much practices organised through collective action contribute to human flourishing (Meyer and Hudon 2019). In the cooperative context, our two-dimensional CPA model addresses essential ethical issues, such as the phenomenon of organisational degeneration, and echoes the recent questioning — with regard to the long history of cooperatives — of the impacts of their actions on communities (Chomel and Vienney 1996). ${ }^{1}$

The agricultural sector offers fertile ground for testing our CPA theoretical approach. Despite its multifaceted challenges, including low economic returns, negative environmental externalities, and pressure from urban sprawl (Wu et al. 2011), the sector is characterised by a dynamic cooperative fabric at grassroots level, which generates innovative socioeconomic and ecological practices in both developed and developing countries (Merrett and Waltzer 2004). This study focuses on a widespread form of these community-based cooperative practices, namely farm machinery sharing arrangements. These arrangements are established by selforganised groups of farmers willing to collectively invest in and manage machinery and other equipment. The presence and institutional nature of these arrangements vary considerably according to national contexts. In France, where these arrangements are most prevalent, approximately half of all farms are members of one of the 12,600 active CUMAs (Coopératives d'Utilisation de Matériel Agricole). Access to affordable, technologically up-to-date machinery is deemed critical to a farm's survival, whatever the national context, because mechanisation costs are one of their largest expenditures. ${ }^{2}$

To explore these burgeoning and innovative yet under-researched farm machinery cooperative agreements, we conduct a systematic literature review (SLR) of 54 documents published 
between 1950 and 2018. This methodology is particularly appropriate for investigating the specificities of commons because it allows the findings from multiple case studies to be generalised. Unlike traditional narrative reviews, SLRs ensure a replicable and transparent research process (e.g. Hansen and Schaltegger 2016; McLeod et al. 2016; Parris and Peachey 2013).

Our findings indicate that members of successful CPAs manage to reach a consensual agreement on quantity and quality dimensions and do not prioritise the former over the latter. Qualitative changes aimed at the common good depend on democratic, participatory debates enabling members to harmonise their values in the CPA decision arena. However, we observe that CPA expansion possibilities - albeit theoretically unbounded - are hindered by (axiological) heterogeneity among members.

The remainder of this paper is organised as follows. Section 2 presents the CPA theoretical framework. Section 3 describes the methodology and introduces the data. Section 4 identifies the benefits and costs for CPA members and examines the critical factors that ensure CPA success. Section 5 discusses the findings, and Section 6 concludes.

\section{Theoretical Framework}

\subsection{The Concept of Common-Property Assets}

CPAs (like CPRs) are characterised by a shared, renewable resource stock that generates a flow of resource units for appropriation or use by individual members (Ostrom 1990). The economic nature of the commons is defined by the criteria of subtractability and excludability (Hess and Ostrom 2003; Ostrom et al. 1994). While high subtractability (i.e. rivalry in the consumption) implies the "congestion, overuse, pollution or destruction [of the shared resource] unless limits are devised and enforced" (Hess and Ostrom 2003, p. 13), it is difficult to prevent a user from 
subtracting units at a moderate cost (excludability). Herein lies the social dilemma of commons management.

To solve this social dilemma, CPRs and CPAs both rely on forms of reciprocity-based institutional arrangements that are neither market- nor state-mediated. CPAs are distinguished from CPRs in two respects. First, while CPRs primarily involve natural resource systems, CPAs are restricted to human-made commons. Second, their ownership structures differ. CPRs can be owned under any property regime, including governmental authorities, community groups, corporations, and private individuals (Hess and Ostrom 2003), while CPAs are exclusively defined by formal or informal common-property ownership regimes to capture cooperative practices. More specifically, of the five property rights (i.e. access, withdrawal, management, exclusion, and alienation) defined by Schlager and Ostrom (1992) as being potentially applicable for CPRs, CPA members share the legal rights only to access, harvest and manage the resource and to legally exclude non-members. The alienation right is considerably limited in CPAs because members cannot sell on their access, use, exclusion, or management rights without the other group members' approval.

Importantly, these two distinctive dimensions interact with one another. CPRs can accommodate flexible bundles of property rights because they rely on pre-existing natural resources. In contrast, because CPAs are created ex nihilo and do not rely on a pre-established substance, their very existence depends solely upon their restrictive ownership structure. In general, CPA members enjoy the usufruct of the assets, but they cannot appropriate them. For example, cooperatives can use the asset-lock principle, whereby a large fraction of the profits is kept in indivisible reserves to be reinvested in assets (Périlleux and Nyssens 2017).

\subsection{Quantity and Quality in Commons}


The two specific CPA attributes we have just expounded introduce major changes in our way of conceiving the sustainable management of commons. We will now examine these changes from a quantity and quality perspective. The quantity perspective largely elaborates on the institutionalist literature that has sought in recent decades to determine the conditions under which collective action and self-governance, especially through the design of a variety of institutional arrangements, could lead to the conservation of natural resources (Baland and Platteau 1996; Ostrom 1990, 1995; Ostrom et al. 1992; Wade 1987). Quantity is defined by the flow of resource units available to users and is affected by two factors: (i) the resource stock and (ii) the institutional arrangements governing the withdrawal policy. In the conventional case of natural CPRs, the resource stock pre-exists collective action and is finite because its increase is limited by biophysical conditions. Accordingly, collective action only focuses on designing institutional arrangements that ensure that the withdrawal rate does not exceed the renewal rate to preserve the CPR quantity. In contrast, CPA users have to agree not only on a practicable withdrawal rate but also on the size of the resource stock (e.g. total production assets), which is adjustable and potentially infinite and dependent entirely and endogenously on collective action.

While the quantity perspective inherently implies a degree of ethical consideration (e.g. fairness of rules), it disregards some key ethical issues, which can be approximated by the concept of the common good. In business ethics, this is defined as "the creation of communities, the values and ties binding social actors, and the positive impacts human activities can have on society" (Meyer and Hudon 2019, p. 279). This concept was nurtured in the Aristotelian ethos of virtue (Sison et al. 2012) and in the social doctrine of the Catholic Church (Argandoña 1998; Melé 2009, 2012). It may also relate to John Dewey's pragmatism (Fesmire 2003). In pursuing the common good, humans as social beings develop themselves as persons-or enhance their “individuality" (Dewey 1986, p. 244) - in their relations with others and concurrently 
contribute to a collective flourishing. Taking serious account of the idea of the common good considerably enhances our thinking on the sustainable management of commons and reveals a number of important ethical issues, which we propose categorising as quality.

We define quality as the positive impact of the users' appropriation of the resource flow on themselves (at individual and collective levels) and their community. Quality derives from a combination of two factors: (i) the substance of the resource stock and (ii) the way in which the commoners appropriate and use the resource flow. In natural CPRs, users can only rely on the latter factor to improve their livelihood because the substance of the resource stock is predetermined. For example, the appropriators of a water basin may institutionalise communitybased practices aimed at preventing contamination and promoting a socially efficient use. In contrast, the members of a CPA define quality by deciding on both the nature of the resource stock and the use of the resource flow. Through collective action, the members determine the type of shared assets (e.g. high-end, environmentally friendly production assets) and the way they use them. For instance, a similar asset may have either a positive or negative impact on the environment according to members' practices and the context in which it is used.

The quality perspective is an under-researched area in the literature on (natural) CPRs. The few studies dealing with this issue have generally considered the goal of improving community livelihood in opposition to the quantitative aspects of natural resource conservation. This opposition is rationalised by misalignments in time horizons. While conservation implies a long-term perspective, users may seek to increase community wellbeing by reaping short-term benefits thereby risking resource depletion (Baland and Platteau 1996). However, more recent evidence indicates that these misalignments are not insurmountable provided that the wider community, rather than just the members, is actively involved in the rule-making process (Persha et al. 2011). 


\subsection{The Conditions of Existence and Expansion for CPAs}

In all CPAs, there is an (explicit or implicit) agreement on the quantity and quality of the units extractable from the resource stock. Each quantity-quality equilibrium materialises in a series of benefits and costs for members at individual level according to their respective discount rates, information-processing abilities, social preferences, community focus, and ethical values. An enriched cost-benefit analysis, which includes rational as well as axiological and sociological elements in decision-making, does not presuppose utilitarian moral theory and coincides with the business ethics perspective on the common good. A cost-benefit analysis typically differentiates direct (tangible) from indirect (intangible) elements in decision-making. Compared to direct benefits and costs, indirect benefits and costs are more difficult to identify and quantify at individual level, and they only appear once the CPA is already established (Schmidtz 2001). Accordingly, direct benefits correspond to economic benefits (e.g. profit increase). Direct costs include the non-strategic, fixed costs inherent to coordination that would exist regardless, even in a hypothetical world where all agents were acting with good will. Indirect benefits, such as experience transfer among CPA members, come about via a mediating effect. Indirect costs are linked to the potentiality of strategic behaviour (i.e. opportunism) from at least some members, including free-riding, monitoring, and enforcement. The aggregation of these benefits and costs at collective level allows us to derive two propositions that characterise the emergence and development of CPAs.

Condition of existence. Members must share a minimal willingness to cooperate in order to launch a CPA. If the level of cooperation is insufficient, no CPA institution will emerge because an insufficient number of members, in their respective individual choice arenas, believe that the direct potential benefits from cooperation surpass the direct costs. Thus, a CPA does not exist until a minimum collective level of cooperation (say $\mathrm{X}$ ) is reached (Proposition $P_{1}$ ). 
Condition of expansion. Once the threshold $X$ is reached, the CPA is established, and the members can begin appropriating the resource flow. In so doing, the CPA members experience unexpected indirect benefits and costs resulting from the collective action. Thus, a CPA is sustainable only if, for a given quantity and quality, the direct and indirect benefits from collective action exceed the direct and indirect costs (Proposition $P_{2}$ ).

How can we identify the conditions for which propositions $P_{1}$ and $P_{2}$ are achievable? Ostrom's (1990) leading work synthesises the factors underpinning the successful management of natural CPRs in eight key design principles for sustainable CPR institutions. In their review of the profusion of empirical studies evaluating Ostrom's (1990) framework, Cox et al. (2010) attest to its relevance and suggest an update of the design principles as follows: (O1) clearly defined users and resource boundaries; $(\mathrm{O} 2)$ appropriation and provision rules congruent with local social and environmental conditions and with users' benefits proportional to the amount of input required; (O3) collective-choice arrangements; (O4) supervision of the condition of the resource and users' behaviour by monitors who are accountable to the users; (O5) graduated sanctions; (O6) conflict-resolution mechanism; and (O7) minimal recognition of rights to

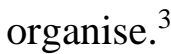

While this analytical framework is useful in terms of understanding the sustainable management of natural CPRs, it is of more limited relevance in the case of CPAs. It succeeds in capturing the cooperative patterns that occur when a CPA is launched (i.e. when the quantitative and qualitative dimensions have already been agreed upon and stabilised by the commoners) but fails to entirely account for the emergence and evolution of a CPA (i.e. how the minimal cooperation threshold $X$ is reached and then exceeded). This updated framework should be therefore supplemented by the CPA group characteristics that initiate and foster within-group cooperation. As suggested by Cox et al. (2010), we draw on Agrawal's (2001) 
framework and retain five attributes from his study: (G1) small size; (G2) successful past experience of collective action by group members; (G3) appropriate leadership; (G4) interdependence among group members; and (G5) group members' shared norms and homogeneity of identities and interests. ${ }^{4}$

Together, Ostrom's (1990) framework as updated by Cox et al. (2010) and Agrawal's (2001) framework provide a robust analytical grid for studying, from an institutionalist perspective, the establishment of institutional arrangements governing CPA organisations-especially in relation to CPA quantity. However, as argued by Meyer and Hudon (2019, p. 288) in their "ethos of social commons", this institutionalist perspective has little to say on the contribution of CPAs to the common good. It should therefore be supplemented by an ethics approach to examine the processes through which the values and preferences embodied in individuals aggregate and transform themselves into collective preferences and choices and to consider the consequences of this transformation on the CPA members and their community. At least two issues could be addressed in an analysis of these processes. First, the institutionalisation process underlying collective action in CPAs raises the question of the place that should be given to rules relative to or in interaction with other (more informal) institutional phenomena, such as shared values and generated moral norms (Jones and Georges 1998). Second, reliance on the concept of the common good requires an examination of the institutional arrangements that enable CPA members to concomitantly foster their individuality and contribute to their community wellbeing (Peredo and Chrisman 2006).

\section{Research Field and Methodology}

\subsection{Overview of Farm Machinery Sharing Cooperative Arrangements}

The agricultural sector is characterised by a dense and vibrant fabric of self-organised, community-level initiatives. Farm machinery sharing arrangements typify these initiatives. 
Although unevenly represented globally, these arrangements are widespread in the major Western countries. Table 1 shows all the countries identified in the literature as having farm machinery sharing agreements and provides estimates of the coverage and most common legal institutional arrangements.

\section{***Insert Table 1 about here ${ }^{* * * *}$}

Among the diversity of farm machinery sharing practices found in the data, the following four institutional forms predominate: mutual aid, machinery partnerships, machinery rings, and machinery cooperatives..$^{5}$ Table 2 presents these four categories (plus that of individual ownership) according to the bundles of property rights available to the respective members. It indicates that only machinery partnerships and machinery cooperatives meet the requirements for classification as CPAs. The common property nature of these two categories gives farmers the rights of access, withdrawal, management, and exclusion, but not alienation. Machinery partnerships are established on a voluntary basis between farmers who need the same type of equipment, with members defining the purchasing and operating policies. This category covers a wide variety of arrangements in terms of degree of formality, ranging from handshake agreements to limited liability corporations (Artz et al. 2010). This is not a recent phenomenon. For example, approximately one-quarter of McCormick's reapers were jointly bought by two or more individuals in the 1850s in the United States (Olmstead and Rhode 1995). Machinery cooperatives are very similar in practice to partnerships but have a stronger common property regime because they operate under the cooperative law.

\section{***Insert Table 2 about here ${ }^{* * *}$}

The categories of mutual aid and machinery rings are excluded from the CPA scope because members have no management or exclusion rights. Mutual aid, which is based on reciprocity between relatives or close neighbours, consists solely of informal arrangements to share 
equipment or to help one another out (if one individual is incapacitated). Machinery rings are associations aimed at coordinating the use of machinery and/or labour among their membership. They do not own any machinery, nor do they undertake any farm work.

In sum, partnerships and cooperatives are representative cases of CPAs in agriculture. Machinery assets are their typical common-property resource stock, and capital depreciation or hours of use are proxies for resource flow.

\subsection{Methodology: Systematic Literature Review}

We conducted a SLR in order to collect a comprehensive sample of empirical studies on farm machinery CPAs in a systematic, transparent, and reproducible manner. While SLRs are now quite common across other disciplines, we are, to our knowledge, the first to apply an SLR to studies on commons management. This SLR approach responds to the main challenge in a study of commons, namely the problem of external validity inherent in case-study methods (Poteete et al. 2009). In our case, this problem is mitigated through generalising the findings from a relatively high number of studies $(\mathrm{N}=54)$ combined with a quality assessment to control for potential selection bias. Our methodological process comprised three major steps: scoping and identification, screening, and coding and evaluation of the final sample (Figure 1).

\section{***Insert Figure 1 about here ${ }^{* * *}$}

Scoping and identification. We defined the scope by specifying the initial search terms in both English and French. ${ }^{6}$ To do this, we first searched private databases and extracted all terms related to machinery sharing agreements in five initial documents. We then searched for these terms in the relevant journals and databases, that is journals related to agriculture and social economy (e.g. Agricultural Economics, Journal of Cooperatives) and field-specific (e.g. AgroDoc, AgEcon) as well as general scientific databases (Web of Science, Scopus, Science Direct, Wiley, and EconLit). Given machinery sharing structures are particularly widespread in 
France, we also conducted an extensive search of specifically French-language databases (Érudit, Persée, ScholarVox). Finally, because academic publications were scant and to reduce potential publication bias, we investigated the grey literature using Google Scholar and ResearchGate. This first search resulted in the identification of 648 sources.

Screening. The vast majority of identified sources were found to be irrelevant, so we drew up the following inclusion and exclusion criteria: (i) all studies describing types of farm machinery sharing agreements under common property were eligible for the sample; (ii) only studies describing at least the creation of the structure and some membership attributes or institutional characteristics of governance (many records mentioned the arrangement without further description) were included; (iii) only sources written in French or English were considered; (iv) no time or geographical restrictions were applied; (v) a study could be in the form of an article, book chapter, report, or other type of work, but newspaper and web articles were excluded; (vi) all studies on any type of machinery sharing were included with the exception of those on irrigation schemes. ${ }^{7}$ In addition, a backward and forward snowballing method was applied after the core body of relevant articles had been identified. This procedure resulted in a final sample of 54 documents covering the 1950-2018 period (see Table A1 in Appendix A). ${ }^{8}$

Coding and evaluation. For the purposes of traceability and replicability, we adopted a thorough coding process that clearly links the primary data sources to the analysis. We first selected all the benefit and cost items that occurred repeatedly in the final sample. We then coded each item 1 if it was mentioned in a given study and 0 otherwise. Likewise, we coded each study 1 if it referenced a design principle (O1-O7) or membership attribute (G1-G5) and 0 otherwise (see Tables B1 and B2 in Appendix B). In addition, we assessed the quality of each publication to control for potential biases. First, we checked for the peer-reviewed attribute of each study. We considered that a study complied with the peer-reviewed attribute only if (i) it was in the form 
of an academic book chapter or (ii) it had either a scholarly publisher with an impact factor at the time of publication or a stated peer-reviewing policy. Second, we checked for any potential conflicts of interest statements in each study. For studies with no statement, we compared the authors' stated affiliations with their research topic (Shamoo and Resnik 2009).

Tables 3 and 4 provide a detailed account of the sample composition. Table 3 indicates that the literature on the topic was scarce and that it pertained to a number of social science disciplines, including business, economics, sociology, history, and ethnology. The included studies predominantly covered industrialised countries, especially France (44\%). This is unsurprising given the proliferation of CUMAs. Table 4 shows that the majority (52\%) of our final sample comprised studies published in peer-reviewed sources by independent researchers.

\section{****Insert Tables 3 and 4 about here***}

\section{Findings}

In this section, we present the findings from our SLR in line with our CPA theoretical approach. We first identify the costs and benefits of being a member of a farm machinery CPA (4.1) and then explore the institutional and ethical conditions for a CPA to emerge and develop (4.2).

\subsection{Decomposing the Benefits and Costs of CPA Participation}

Based on our SLR, we decompose in Table 5 the various types of benefits and costs underpinning the formulation of our propositions $P_{1}$ and $P_{2}$.

\section{***Insert Table 5 about here***}

The benefits of participating in a CPA can be either direct or indirect. Direct benefits are realmoney advantages that lead to sizable profit increases. These profit increases can result either 
from huge reductions in mechanisation costs $(98 \%)^{9}$ or from productivity gains $(87 \%)$, which derive from access to more advantaged technologies at a competitive price. Indirect benefits essentially emerge, on the one hand, from the diffusion of up-to-date technologies, which both improve the working environment and environmentally friendly practices (80\%) and reduce risk (59\%), and, on the other, from virtuous group dynamics, such as mutual aid (57\%) and a “stimulus" effect (22\%) (Putterman 1983, p. 82). This diffusion is encouraged through 'learning by doing' processes, which enable farmers to share experiences within their CPA group.

Direct costs are opportunism-free and mostly include timeliness costs, which arise simply because the machinery cannot be in two places at once. These costs, which were reported in the vast majority of the studies (80\%), generally increase with the frequency and time-sensitivity of machinery use. They logically peak during high seasonal activities (when all CPA members have the same equipment needs) and sometimes derive from machinery failures brought about by members' lack of skills or training. Historically, timeliness costs have been accorded great significance. For instance, they are deemed to have been the main reason for farm machinery cooperative failures in the 1930s and 1960s in the United States (USDA 1980). Indirect costs result from opportunism (Allen and Lueck 1998). While a significant portion of our sample refers to the potentiality of moral hazard phenomena, these are only documented in $39 \%$ of the studies. Larsén (2007, p. 23) notes that partnerships "are often characterized by personal relations among the collaborating farmers (friends, neighbours, relatives) and it is reasonable to believe that shirking in effort is more costly in social terms when one has a personal relation to his/her partners at the same time as the level of trust is likely to be higher". However, we cannot exclude the possibility that this relatively uncommon citing of strategic behaviours in our sample derives from the fact that social scientists underestimate the survivorship bias (Poteete et al. 2009) by focusing on successful institutions (Acheson 2006). 


\subsection{The Determinants of Cooperation: What Brings Members Successfully Together}

Our examination of the benefits and costs related to farm machinery sharing cooperative practices reveals that satisfying the conditions of existence $\left(P_{1}\right)$ and expansion $\left(P_{2}\right)$ is not necessarily an easy task. Using our theoretical framework, which combines an institutionalist and an ethics approach, we investigated the set of strategies that the CPAs in our study adopted to successfully satisfy these two conditions. Tables 6 and 7 summarise our findings. The prevalence computed for each item (i.e. $O_{n}$ and $G_{n}$ ) clearly indicates whether and, if so, how far a particular CPA strategy validates $P_{1}$ and $P_{2} \cdot{ }^{10}$

\section{****Insert Table 6 about here ${ }^{* * *}$ \\ ***Insert Table 7 about here ${ }^{* * *}$}

\section{An Institutionalist Analysis of Collective Action in Farm Machinery CPAs}

Support for Proposition $P_{1}$. The formation of a new CPA never comes out of the blue. It generally emerges from a pre-existing social capital, which is based either on previous formal or informal machinery sharing agreements or on experience in other types of cooperative practices. This social capital is strongest when it derives from positive previous collaborations between members of the (new) CPA (G2 [50\%]). The presence of appropriate leadership, comprising well-integrated, charismatic, trustworthy farmers who are willing to cooperate with their peers, proves crucial in terms of turning the social capital to good account (G3 [44\%]). External situational factors, such as a supportive network (e.g. the CUMA federation in France) and favourable legislation, are also decisive in fostering trust among farmers ( $\mathrm{O} 7$ [80\%]). Finally, membership homogeneity, in terms of endowments (farm size), interests (farming activities), and cognitive abilities, enhances cooperation in the early stages of a CPA (G5). 
Support for Proposition $P_{2}$. Once a CPA has formed, trust is sustained by a set of institutional arrangements. Table 6 reveals that very few (9\%) of the studies reviewed allude to the item 'graduated sanction mechanisms' (O5). Likewise, few report a breach of a CPA's collectively crafted rules. A combination of three factors may explain these counterintuitive results. First and foremost, $93 \%$ of the studies indicate that successful CPAs are groups with clearly defined user and resource boundaries. The degree of formality of the sharing arrangement generally increases as a function of group size (O1). Second, farmers tend to favour small groups, which create a high level of trust (G1 [55\%]) through regular face-to-face meetings, direct communication, and informal conflict resolution ("by sitting down right away") (Harris and Fulton 2000c, p. 21), thereby avoiding costly formal procedures (O6 [48\%]). Third, the design principle whereby a designated monitor is accountable for a subpart of the commons (i.e. a piece of machinery) vis-à-vis the other CPA members also appears in $35 \%$ of the studies. The monitor's role is critical in the event of damage to a piece of machinery because he or she determines whether the deterioration arises from user negligence or obsolescence $(\mathrm{O} 4)$.

A heterogeneous membership is prone to noisy communication and tensions. At operational level, members display a preference for cooperating with peers who exhibit similar practices to their own concerning the use and maintenance of farm machinery, thereby highlighting the fact that membership homogeneity mitigates collective action costs. Interestingly, in contrast with the oft-mentioned time horizon problem in cooperatives (Jensen and Meckling 1979), there is no clear-cut evidence of any negative impact from heterogeneity in member age in terms of level of cooperation. While homogeneity in the membership profile is structurally beneficial for cooperation, it may impede synergies if it is too excessive. As mentioned in $80 \%$ of the studies, synergies imply a strong interdependence among members and are only attainable if the CPA has achieved a high level of cooperation. These synergies derive from the farmers' 
specialisations in technical tasks based on their skills, knowledge, and preferences. CPAs also adopt routines by having specific tasks always performed by the same members to alleviate the coordination costs stemming from interdependence. At the same time, the farmers' withingroup specialisations stimulate group cohesion. On an unrelated note, heterogeneity in farming activities or in soil characteristics helps reduce timeliness costs (G4).

\section{An Ethics Analysis of Collective Action in Farm Machinery CPAs}

Support for Proposition $P_{1}$. The formation of a CPA requires the pre-existence of shared ethical values, including "kinship, personal compatibility, utility, practicality, and reciprocity" (Gröger 1981, p. 173). This is referred to in $69 \%$ of the cases. In the French context, which is the best documented, the emergence of CUMAs was marked by a diverse ideological breeding ground that included socialist but primarily Christian-personalist philosophies. For instance, after WWII, "a powerful youth movement gained momentum in [sic] countryside: the 'Jeunesse Agricole Catholique' ([Christian agricultural youth], JAC) [...] focussed on the social and economic emancipation of rural youth by getting away from dependence on the traditional relations in which they were rooted" (Herbel et al. 2015, p. 29). Likewise, Pierre (2009, p. 144) reports that "the farming professional movements [...] have been, greatly impregnated by the ideology of the JAC, extolling values of cooperation and solidarity between producers in a modernist evolution". Interestingly, in countries that have experienced sudden ideological shifts (such as post-communist Eastern European countries), indifference towards any form of cooperative action is a major obstacle to the creation of farm machinery CPAs. In these contexts, only basic forms of mutual aid among relatives or close friends is achievable (G5).

Support for Proposition $P_{2}$. When a CPA expands, ethical considerations play a critical role in creating a shared identity. These are expressed in different ways. First, social preferences, predominantly fairness, represent a sine qua non for CPA success. In particular, fairness is 
instrumental to a membership's ability to cope with one of the major challenges in farm machinery CPAs, that is operation timeliness. In $72 \%$ of the studies, well-documented strategies are reported for deciding who has the right to use a piece of machinery when more than one farmer needs it while ensuring fairness among all CPA members. These include randomly drawing the order of use, annual rotation of the starting date for machinery use, and fixing a limited number of hours or acres per use. In this respect, equality appears to be an option in order to avoid conflicts among members, in other words farmers will "go around and do a little bit of everybody's [fields]" (Artz et al. 2010, p. 812). Natural variables may also be used as criteria to determine the sequencing of machinery use because they appear more objective and neutral. For example, physical variations across members' farms (e.g. climate-sensitivity, elevation, soil nature) or agronomic considerations (e.g. crop precocity) may be exploited. Interestingly, while the choice of allocative strategy (which regularly evolves) may maximise the sense of fairness among the CPA members, it may not necessarily be the best one in terms of economic efficiency (O3). Second, CPA rules are devised locally, consensually, and according to within-group practices. It is also common (65\% of the cases) that groups combine formal and informal (i.e. written and unwritten) rules. The legitimacy of the within-group rules derives from a democratic and transparent governance. For example, "with four members, you can expect to get your way one-fourth of the time" (Artz et al. 2010, p. 814). The higher the legitimacy, the higher the compliance with collective rules $(\mathrm{O} 2)$. Third, the ethical perspective offers a convincing explanation for the low 'graduated sanctions' presence rate (O5 [9\%]). Formal rules are not sufficient and may even be counter-productive for stimulating integrity and cooperative behaviours, as Barthélémy de Saizieu (1984, p. 365) observes: “[some CUMAs] deliberately dispensed with the legal safeguards that usually accompany the cooperative status, thereby reinstating the trust-based relationship among their members that regulated labour exchanges in the past (spontaneity, mutual aid, disinterestedness). [...] As non- 
compliance with the inherent CUMA obligations is no longer punishable by a higher authority, abiding by them becomes a matter of honour" [our translation].

Importantly, the initial set of ethical values that launch a new CPA is not ossified for the whole of the CPA's existence. As suggested by Ahn and Ostrom (2008), if the early stages of the CPA are conclusive, the group's axiological cement may strengthen and allow for a supplementary layer of social capital and a reinforcement of its common bond. The CPA members, both individually and as a group, are likely to gain self-confidence and upgrade the social representation of their role not only within the agricultural sector but also in the community and society more broadly. CPAs can act as institutional facilitators that continuously enable members to introduce and share their own ethical values. This catalytic process typically hinges on participatory and democratic procedures. This is the case with the French CUMAs, where the 'one member, one vote' rule applies. Developing values in a collective setting is likely to transform the qualitative nature of the shared resource stock. Indeed, farm machinery cooperatives play an increasingly pivotal role in fostering a more sustainable management of primary production not only by improving farmers' economic situations (Artz 2014; De Toro and Hansson 2004) but also by promoting agro-ecological practices and building alternative distribution channels that better comply with consumers' ethical preferences (Lucas and Gasselin 2018; Lucas et al. 2019). Along with their positive contribution to the community, CPA members may also enhance their own individuality through their participation in collective action, for example by gaining in autonomy. A significant proportion of the studies reveal that while cooperation brings its own set of rules and norms, farmers often acknowledge that this is a necessary prerequisite for ensuring their autonomy. As noted by Pierre and Thareau (2011, p. 111), "being autonomous also means being less dependent on market fluctuations and changes in public policy and being able to act on these dimensions" [our translation]. Moreover, 
CPAs appear to be a means of fostering the individuality of the most vulnerable by enabling them to cope with a crisis environment, thereby preserving the existence of small farmers in communities (Almås 2010; Gröger 1981) (G5).

Finally, approximately half of the studies (43\%) stress the importance of leadership. By balancing rule-driven and value-driven leadership, leaders play a key role in all these processes impacting the quantity and particularly the quality of CPAs. As noted by Lanneau (1969, p. 43), leaders are "less chiefs than conciliators", and their mission consists in defusing within-group tensions and fostering moral norms among members. Leaders also act as facilitators, interacting with all external stakeholders likely to increase their CPA's organisational performance (e.g. local government representatives, agricultural advisers, institutional networks) and taking into account the community's aspirations (G3).

\section{Discussion}

\subsection{On Determining Quantity and Quality in Farm Machinery CPAs}

We begin by discussing the two factors affecting CPA quantity. Regarding the first factor (i.e. institutional arrangements defining withdrawal policy), our findings indicate that farm machinery sharing CPAs intensively apply some of Ostrom's (1990) updated principles in order to prevent some members from opportunistically overusing the resource. The resource stock boundaries and the resource flow beneficiaries are clearly defined in a combination of formal and informal collectively designed arrangements, which fit with the CPA's specific, local context. However, Ostrom's (1990) cornerstone principle of graduated sanctions is virtually absent from all the studies reviewed. Supplementing the institutionalist analysis with an ethics analysis allows us to understand this surprising finding. In particular, our findings suggest that members manage to cope with operation timeliness (the main issue in farm machinery sharing CPAs) by setting up fair, consensual rules, which reduces the need to design sanction 
mechanisms. Moreover, our results reveal that some CPAs deliberately dispense with (formal) rules governing their operations in order to stimulate honour and commitment. This echoes the research in ethics showing that in 'prisoner's dilemma' situations, rules (providing for sanctions) may be counter-productive to generating shared moral norms and cooperative behaviours (Scalet 2006).

Regarding the second factor (i.e. the size of the resource stock), our findings indicate that the stock's initial size depends on the pre-existing level of trust and social capital, which is made up of previous positive cooperative experiences that may or may not be linked to machinery sharing agreements. Moreover, our analysis unequivocally shows that the resource stock is limited in breadth and depth. In terms of depth limitation, despite the fact farmers in a CPA could potentially reach a 'kibbutz-style' model by increasing their cooperation efforts, there was no evidence of such a fully integrated form in our sample. The main factor impeding full integration appears to be membership heterogeneity - even though member interdependence may partially act as a counterbalancing factor. In keeping with the institutionalist view on cooperative governance (e.g. Abramitzky 2011; Burdín 2016; Hansmann 2000), pushing the CPA resource stock beyond the threshold could undermine the delicate incentive structure that harmonises heterogeneous economic member profiles (i.e. varying degrees of abilities, interests, or endowments). Breadth limitation relates to limited group size, which appears to be a key success factor for CPAs. Relatively small operational scales ensure more effective design and rule enforcement and other more informal institutional arrangements (e.g. shared norms), thereby maintaining a high level of trust and hence a sustainable CPA quantity.

On the question now of how members reach a consensus on quality, we delve into the ethical layer underpinning collective action. Our findings show that the initial quality of the shared resource stock relies on diverse ethical sources, including socialism and primarily Christian 
personalism. Discovering these two ideologies in this context is unsurprising because they have been influentially "competing and overlapping" throughout the history of cooperation (Menzani and Zamagni 2010, p. 104). Indeed, the very first cooperative, the Rochdale Society, which was established in England in 1844, was marked by a synthesis of these two ideologies (Davis and Worthington 1993). More generally, this diversity also reflects the idea that "business ethics has its intellectual and historical roots in philosophy and religious ethics" (Greenwood and Freeman 2017, p. 1).

Our analysis also reveals that this initial set of values evolve and may lead the CPA members, individually or collectively, towards the common good. This sense of community can bring about qualitative changes in the CPA, such as a quest for regaining control in relation to market fluctuations and public policies changes, and a shift towards energy self-sufficiency and environmentally friendly practices (Van der Ploeg 2012). These qualitative changes result in an adjustment in the substance of the resource stock and/or in the way of using the existing machinery (e.g. redirecting the use of a tractor towards organic farming). Such qualitative changes are typically possible in CPAs that are arenas favouring democratic and participatory debates. From a Deweyan perspective, such debates enable CPA members to trial actions and evaluate the consequences of these actions on the 'publics' impacted by the CPA, thereby increasing the chances of a positive impact on the community (Dewey 1927; Sacchetti 2015). In this evaluative enterprise, moral leaders appear to play a decisive role by encouraging members to adopt reflexive conduct (Gini 2004). One example of this is the French CUMAs, which are thought of as one of the last remaining spaces in which farmers with diverse axiological representations on agriculture maintain dialogue and - to some extent at leastharmonise views (Cordellier 2014). However, while such a dialogue process can produce desirable outcomes, a full convergence on ethical values is not necessarily possible, especially 
when the cooperation level among CPA members is already high (Emery 2014). In particular, the strong polarisation of farming systems (e.g. technology-intensive factory farms versus family farms) that characterises today's agricultural context in Western countries reflects a lower axiological common denominator among farmers and is likely to complicate any agreement on the qualitative aspects of farm machinery CPAs (Bokusheva and Kimura 2016).

In sum, just as there is a threshold effect on CPA quantity, there is also a threshold effect on CPA quality. This implies that an increase in CPA quantity, while breaking through the quality threshold, is likely to endanger CPA governance. Indeed, if CPA members stop adhering to the business ethics conveyed (implicitly) by the commons, cooperation may be negatively affected.

\subsection{Using the CPA Approach to Investigate Ethical Issues in Cooperatives}

Our CPA framework substantially expands the functional view of cooperatives offered by mainstream economics, which holds that a cooperative remains fixed and essentially restricted to purely economic concerns (e.g. Cook et al. 2004). This idea can be illustrated by tentatively applying our CPA model to a different context, namely credit cooperatives. As suggested by the relevant literature, quantity equates to the total volume of credit (in monetary units) available to borrowers. This combines bank equity (which proxies the resource stock) and the rules governing credit-granting operations that allow bank equity to be maintained (Périlleux and Nyssens 2017). However, our approach extends the existing literature by examining the other dimension characterising a banking CPA, that is its quality. The quality of an available loanable monetary unit is affected by credit conditions and the lending technology (i.e. the substance of the resource stock). This captures a first set of ethical issues in credit operations. For example, setting fair interest rates has strong implications for vulnerable borrowers (Hudon 2007). The quality of credit is also strongly dependent on whether and, if so, how much borrowers use the money entrusted to them by the bank for endeavours set up in the pursuit of 
the common good. This corresponds to a second set of ethical issues, which for instance accounts for novel trends in finance like the nascent field of social banking (Cornée and Szafarz 2014). More generally, our two-dimensional CPA model explains the recent shift observable in the field of cooperative studies. Cooperatives are no longer seen as organisations focused solely on satisfying their members' interests but increasingly as organisations oriented towards community wellbeing (Gui 1991). The theorisations of social and community-based enterprises have largely contributed to this evolution (Borzaga and Defourny 2001; Peredo and Chrisman 2006).

Our two-dimensional framework also captures one of the main cooperative dilemmas, that is the 'cooperation tragedy'. The development of growth strategies by cooperatives to survive in their environment often engenders detrimental ethical consequences, which materialise in loss of membership commitment, degeneration, and demutualisation (Jones and Kalmi 2012). In our CPA framework, this situation characterises a quantity-quality mismatch. The recent waves of mergers among local cooperative banks in Italy_which have brought minor efficiency gains but seriously harmed small-scale, marginalised borrowers-illustrate the ethical risk of prioritising quantity over quality (Coccorese and Ferri 2020). However, smallness is not in itself a panacea for aligning the two CPA dimensions. In our study, CPAs benefitting from the presence of a supportive federative network, like the CUMAs in France, clearly appear to encounter less difficulty in intensifying cooperation and in passing the CPA on to the next generation of commoners than those with no such supportive federation (e.g. in the US). Such organisational features are very similar in nature to the initial doctrine prevailing in cuttingedge cooperative experiences like the Raiffeisen Credit Cooperatives, the Mondragon Cooperative Corporation, and the kibbutzim in Israel, which intentionally limited the size of their grassroots organisations while achieving scale economies through coordinating at an upper layer (Forcadell 2005; Guinnane 2001; Ingram and Simons 2002). Thus, CPAs should not be 
considered in isolation when identifying the organisational features that harmonise quantity and quality. On the contrary, they should be viewed as basic units that pertain to complex systems of polycentric governance, which include nested decision-making levels, federative layers, and the recognition of public authorities (Ostrom 2010).

\section{Conclusion}

This study marks the first step towards a more comprehensive theory of CPAs that aims to adapt the commons paradigm to the realm of cooperatives. Based on a SLR, we use our CPA model to scrutinise the emergence and expansion conditions of multiple farm machinery sharing agreements. The main conclusion from our institutionalist and ethics analyses is that sustainable CPA governance is achievable when members consensually converge on and endorse a quantity-quality equilibrium. However, the existence of threshold effects for both quantity and quality, which result from irreducible member heterogeneity for both economic and axiological reasons, indicates that a CPA thrives when collectivising production assets matches its everevolving membership's ethical preferences and community aspirations.

Our study could be expanded along at least three research avenues. First, the critical issue of membership heterogeneity calls for future qualitative research to examine the harmonisation processes of dissonant individual value systems in collective action (Stark 2011) and to determine how these processes, when they are democratic, produce desirable outcomes for the community (Sacchetti 2015). Second, our research highlights the need to conduct multiple case studies and to generalise their findings in order to identify the right scheme of polycentric governance that ensures a convergence on the quantitative and qualitative dimensions of CPAs (Pohler et al. 2017). The SLR methodology we have introduced to study the commons could be particularly helpful in this endeavour. Third, there is considerable room for further research on 
quality measurement. While CPA quantity is by definition easily calculable, the measurement of CPA quality is much more challenging.

While our study focuses predominantly on industrialised countries, farm machinery CPAs represent a promising way of improving quality of life for the world's 500 million smallholders, who account for around $80 \%$ of global food production, by both increasing productivity and generating positive externalities for communities (Nouwogou 2016). More generally, although economists have long accused common-property regimes of inefficiency, we can confirm that there is room for collective action and community-based cooperative practices in combination with the private and public spheres as a successful global solution to fair and sustainable development. 


\section{Notes}

${ }^{1}$ We refer here to the seventh principle of the International Cooperative Association: "co-operatives work for the sustainable development of their communities through policies approved by their members" (Chomel and Vienney 1996, p. 5).

${ }^{2}$ In US farms, machinery costs can amount to as much as $41 \%$ of annual farm production costs (Wolfley et al. 2011). In Quebec, equipment purchasing accounts for $20-25 \%$ of total expenses for dairy farmers (Harris and Fulton 2000a). In French farms, mechanisation represents $19 \%$ of operating expenses and $29 \%$ of fixed assets (AGRESTE 2016).

${ }^{3}$ Cox et al. (2010) splits Ostrom's (1990) principles 1, 2 and 4 into two subcomponents (e.g. 'clearly defined boundaries' becomes 'clearly defined users' boundaries' and 'clearly defined resource boundaries'). Because we also investigated membership characteristics in detail, we decided to merge the subcomponents of these principles into one comprehensive principle (e.g. 'clearly defined user and resource boundaries'). On an unrelated note, Ostrom (1990, p. 90) identifies a further design principle, O8 'nested enterprises', “for CPRs that are part of larger systems". Due to this specific attribute, it is mentioned in our discussion section (Section 5).

4 Agrawal's (2001) article initially considers 'shared norms' and 'homogenous identities and interests' as two different variables. In order to produce a clear framework, we decided to merge these variables because the descriptions of the CPA groups in our sample were generally not extensive enough to address them separately.

${ }^{5}$ These forms are not mutually exclusive. Farmers often rely simultaneously on several of them (Thomas et al. 2015).

${ }^{6}$ The final search terms were (in alphabetical order): coop* for the use of farm implements; coop* for the use of agricultural equipment; CUMA; farm machinery coop*; joint machinery pool; machinery ring; machinery sharing; machinery-use cooperative; partage de matériel agricole. The variant 'co-operative' was also included. 
${ }^{7}$ Studies on irrigation CPRs, which are better represented in the literature (Tang 1992; Wade 1987), may have obfuscated the findings on traditional farm machinery sharing arrangements.

${ }^{8}$ These 54 articles are marked with an asterisk in the reference list.

${ }^{9}$ Throughout this section, the percentages in parentheses correspond to the prevalence of the item among the studies reviewed.

${ }^{10}$ As explained in Section 3.2, our methodology ensures that we have not arbitrarily ruled out any given strategy. In particular, no item reports strategies that are not described in independently authored, peer-reviewed sources. 
References (Articles in the SLR are marked with an asterisk)

Abrahamsson, G. (2015). We run the network of information exchange around the work of machinery rings in Europe. In Association of the European national MR-federations (EMR e.V.). Neuburg, Germany. December 2015.

Abramitzky, R. (2011). Lessons from the Kibbutz on the equality-incentives trade-off. Journal of Economic Perspectives, 25(1), 185-208.

Acheson, J. (2006). Institutional failure in resource management. Annual Review of Anthropology, 35(1), 117-134.

Agrawal, A. (2001). Common property institutions and sustainable governance of resources. World Development, 9(10), 1649-1672.

AGRESTE (Service de la Statistique du Ministère de l'Agriculture) (2016). L'équipement des exploitations agricoles. Primeur, 334, 1-8.

Ahn, T., \& Ostrom, E. (2008). Social capital and collective action. In D. Castiglione, J. van Deth, \& G. Wolleb (Eds.), The handbook of social capital, (pp. 70-100). Oxford: University Press.

Allen, D., \& Lueck, D. (1998). The nature of the farm. Journal of Law and Economics, 41(2), 343-386.

*Almås, R. (2010). I have seen the future and it works! In A. Bonanno, H. Bakker, R. Jussaume, Y. Kawamura, M. Shucksmith (Eds.), From community to consumption: New and classic, (pp. 3-16). Bingley: Emerald Group Publishing Limited.

*Andersson, H., Larsén, K., Lagerkvist, C., Andersson, C., Blad, F., Samuelsson, J., \& Skargren, P. (2005). Farm cooperation to improve sustainability. AMBIO: A Journal of the Human Environment, 34(4-5), 383-387.

Argandoña, A. (1998). The stakeholder theory and the common good. Journal of Business Ethics, 17(9-10), 1093-1102.

*Artz, G., Colson G., \& Ginder, R. (2010). A return of the threshing ring? A case study of machinery and labor-sharing in Midwestern farms. Journal of Agricultural and Applied Economics, 42(4), 805-819.

Artz, G. (2014). Equipment sharing in agriculture. In P.B. Thompson, \& D.M. Kaplan (Eds.) Encyclopedia of food and agricultural ethics, (pp. 595-600). Dordrecht: Springer.

*Artz, G., \& Naeve, L. (2015). Scaling up fruit and vegetable production: Is machinery sharing a possibility? Professional Agricultural Workers Journal, 3(1), 1-10.

*Artz, G. \& Naeve, L. (2016). The benefits and challenges of machinery sharing among smallscale fruit and vegetable growers. Journal of Agriculture, Food systems, and Community Development, 3(6), 19-35. 
Baland, J-M., \& Platteau, J-P. (1996). Halting degradation of natural resources: Is there a role for rural communities? Oxford: Clarendon Press.

*Baranyai, Z., Szabó, G., \& Vásáry, M. (2014). Analysis of machine use in Hungarian agriculture. Is there any future for machinery sharing arrangements? Annals of the Polish Association of Agricultural and Agribusiness Economists, 16(3), 24-30.

*Barthélémy de Saizieu, T. (1984). Les formes actuelles de l'entraide agricole dans une commune de basse-Bretagne. Ethnologie Francaise, 4(14), 363-376.

*Basarik, A. \& Yildirim, S. (2015). A case study of sharing farm machinery in Turkey. International Journal of Natural and Engineering Sciences, 3(9), 1-6.

*Beaudry, R., Denis, C. \& Saucier, C. (2002). Entre l'enthousiasme et l'inquiétude. Collection études théoriques, CRISES, Québec.

Bollier, D. (2011). The growth of the commons paradigm. In C. Hess, \& E. Ostrom (Eds.), Understanding knowledge as a commons: From theory to practice, (pp. 27-40). Cambridge: The MIT Press.

Bokusheva, R. \& Kimura, S. (2016). Cross-country comparison of farm size distribution. OECD Food, Agriculture and Fisheries Papers 94, OECD Publishing, Paris.

Borzaga, C. \& Defourny, J. (2001). The emergence of social enterprise. London \& New York: Routledge.

Burdín, G. (2016). Equality under threat by the talented: Evidence from worker-managed firms. Economic Journal, 126(594), 1372-1403.

*Capitaine, M. (2005). Organisation des territoires des exploitations agricoles. Impact du recours à des collectifs d'action : la conduite de chantiers de récolte en CUMA, Unpublished doctoral dissertation, Institut National Polytechnique de Lorraine, Nancy.

*Capitaine, M., Benoît, M. \& Baudry, J. (2008). Mutualisation du travail et compétences territoriales. In Coopératives, développement et territoire - Formes coopératives de partage et organisation du travail, Colloque SFER. Paris, France. February 2008.

*Chalopin A. \& Masson, P. (1999). Construction de la CUMA-compost. Économie Rurale, 253, 106-107.

Chomel, A., \& Vienney, C. (1996). Déclaration de l'ACI: la continuité au risque de l'irréalité. Annals of Public and Cooperative Economics, 67(4), 655-664.

*Cocaud, M. (2001). Un cadre associatif pour l'innovation technique dans les campagnes bretonnes du XXIème siècle. Annales de Bretagne et des Pays de l'Ouest, 108, 135-145.

Coccorese, P., \& Ferri, G. (2020). Are mergers among cooperative banks worth a dime? Evidence on efficiency effects of M\&As in Italy. Economic Modelling, 84, 147-164. 
Cook, M. L., Chaddad, F. R., \& Iliopoulos, C. (2004). Advances in cooperative theory since 1990: A review of agricultural economics literature. In G. Hendrikse (Ed.) Restructuring agricultural cooperatives, (pp. 65-90). Rotterdam: Erasmus University Rotterdam Press.

*Cordellier, S. (2014). Une histoire de la coopération agricole de production en France. Revue Internationale de l'Economie Sociale, 331, 45-58.

Cornée, S., \& Szafarz, A. (2014). Vive la difference: Social banks and reciprocity in the credit market. Journal of Business Ethics, 125(3), 361-380.

Cox, M., Arnold, G., \& Villamayor Tomás, S. (2010). A review of design principles for community-based natural resource management. Ecology and Society, 15(4), 38-57.

*Cropp, R., \& Ford, C. (2002). An analysis of machinery cooperatives for dairy farms in the upper Midwest, UWCC Staff Paper No. 1, University of Wisconsin Center for Cooperatives, Madison.

*Cush, P., \& Macken-Walsh, A. (2016). The potential for joint farming ventures in Irish agriculture: A sociological review. European Countryside, 8(1), 33-48.

Dardot, P., \& Laval, C. (2014). Commun. Essai sur la révolution au XXe siècle. Paris: La Découverte.

Davis, P., \& Worthington, S. (1993). Cooperative values: Change and continuity in capital accumulation the case of the British Cooperative Bank. Journal of Business Ethics, 12(11), 849-859.

*De Toro, A., \& Hansson, P. (2004). Machinery co-operatives. A case study in Sweden. Biosystems Engineering, 87(1), 13-25.

Dewey, J. (1927). The public and its problems. New York: Holt.

Dewey, J. (1986). Mediocrity and individuality. The Educational Forum, 50(3), 357-362.

*Edwards, E. (2013). Joint machinery ownership. Extension service ag decision maker series A3-34, Iowa State University Extension, Ames.

Emery, S. (2014). Independence and individualism: Conflated values in farmer cooperation? Agricultural and Human Values, 32(1), 1-15.

Fesmire, S. (2003). John Dewey and moral imagination: Pragmatism in ethics. Bloomington: Indiana University Press.

Flanigan, S., \& Sutherland, L. (2016). Buying access to social capital? From collaboration to service provision in an agricultural co-operative. Sociologia Ruralis, 56(4), 471-490.

FNCUMA (2019). CUMA: Chiffres clefs 2019. Paris: Fédération Nationale des CUMA.

Forcadell, F. J. (2005). Democracy, cooperation and business success: The case of Mondragón corporación cooperativa. Journal of Business Ethics, 56(3), 255-274. 
*FWA (Fédération Wallonne de l'Agriculture) (2012). Dossier coopératives. Pleinchamp, 40, $13-22$.

*Gertler, M. (1981). A Comparison of agricultural resource management on selected group and individual farms in Saskatchewan, Unpublished doctoral thesis, Faculty of Graduate Studies and Research of McGill University, Montreal.

Giagnocavo, C., \& Vargas-Vasserot, C. (2012). Support for farmers' cooperatives: Country report Spain. Wageningen: Wageningen UR.

Gijselinckx, C., \& Bussels, M. (2012). Support for farmers' cooperatives: Country report Belgium. Wageningen: Wageningen UR.

Gini, A. (2004). Moral leadership and business ethics. In J. B. Ciulla (Ed.), Ethics, the heart of leadership, 2nd edition, (pp. 25-43). Westport, CT: Quorum Books.

Greenwood, M. \& Freeman, R. E. (2017). Focusing on ethics and broadening our intellectual base. Journal of Business Ethics, 140(1), 1-3.

*Gröger, B. (1981). Of men and machines: Co-operation among French family farmers. Ethnology, 20(3), 163-176.

Gui, B. (1991). The economic rationale for the 'third sector'. Annals of public and cooperative economics, 62(4), 551-572.

Guinnane, T. W. (2001). Cooperatives as information machines: German rural credit cooperatives, 1883-1914. The Journal of Economic History, 61(2), 366-389.

Hansen, E. G., \& Schaltegger, S. (2016). The sustainability balanced scorecard: A systematic review of architectures. Journal of Business Ethics, 133(2), 193-221.

Hansmann, H. (2000). The ownership of enterprise. Cambridge: Harvard University Press.

Hardin, G. (1968). The tragedy of the commons. Science, 162(3859), 1243-1248.

*Harris, A., \& Fulton, M. (2000a). The CUMA farm machinery co-operatives. Center for the Study of Co-operatives, University of Saskatchewan, Saskatoon.

*Harris, A., \& Fulton, M. (2000b). Farm machinery co-ops: An idea worth sharing. Center for the Study of Co-operatives, University of Saskatchewan, Saskatoon.

*Harris, A., \& Fulton, M. (2000c). Farm machinery co-operatives in Saskatchewan and Québec. Center for the Study of Co-operatives, University of Saskatchewan, Saskatoon.

Hess, C. (2008). Mapping the new commons. In Governing shared resources: Connecting local experience to global challenges (pp. 1-75). 12 $2^{\text {th }}$ biennial conference of the international association for the study of the Commons. Cheltenham, England. July 2008.

Hess, C., \& Ostrom, E. (2003). Ideas, artifacts, and facilities: Information as a common-pool resource. Law and Contemporary Problems, 66(1), 111-146. 
*Herbel, D., Rocchigiani, M., \& Ferrier, C. (2015). The role of the social and organizational capital in agricultural co-operatives' development: Practical lessons from the CUMA movement. Journal of Co-operative Organization and Management, 3(1), 24-31.

*Hofstrand, D. (2000). Labor and machinery sharing agreement. Extension service ag decision maker series C4-45, Iowa State University Extension, Ames.

Hudon, M. (2007). Fair interest rates when lending to the poor. Ethics and Economics, 5(1), 18.

Ingram, I., \& Simons, T. (2002). The transfer of experience in groups of organizations: Implications for performance and competition. Management Science, 48(12), 1517-1533.

*Jannot, P., \& Vaquié, F. (1997). Les conditions d'adoption d'une solution innovante d'équipement : Le groupe tracteur. Ingénieries, 11, 17-26.

*Jeanneaux, P., Capitaine, M., \& Mauclair, A. (2018). PerfCuma: A framework to manage the sustainable development of small cooperatives. International Journal of Agricultural Management, 7(1), 54-65.

Jensen, M. C., \& Meckling, W. H. (1979). Rights and production functions: An application to labor-managed firms and codetermination. Journal of Business, 52(4), 469-506.

Jones, G. R., \& Georges, J. M. (1998). The experience and evolution of trust: Implications for cooperation and teamwork. The Academy of Management Review, 23(3), 531-546.

Jones, D. C., \& Kalmi, P. (2012). Economies of scale versus participation: A co-operative dilemma? Journal of Entrepreneurial and Organizational Diversity, 1(1), 37-64.

Kalmi, P. (2007). The disappearance of cooperatives from economics textbooks. Cambridge Journal of Economics, 31(4), 625-647.

*Kenkel, P., \& Long, G. (2007a). Feasibility of machinery cooperatives in the Southern plains. In Southern agricultural economics association. Mobile, Alabama. February 2007.

*Kenkel, P., \& Long, G. (2007b). Structural considerations for machinery cooperatives. In NCERA-194 annual meeting. Minneapolis, Minnesota. November 2007.

*Lagerkvist, C., \& Hansson, H. (2012). Machinery-sharing in the presence of strategic uncertainty: Evidence from Sweden. Agricultural Economics, 43(s1), 113-123.

*Lanneau, G. (1969). Agriculteurs et coopération. Archives Internationales de Sociologie de la Coopération, 26, 131-200.

*Lanneau, G. (1984). Stratégies coopératives chez les agriculteurs à travers leurs pratiques. In L'économie sociale en agriculture et en milieu rurale (pp. 214-221). Paris, France. March 1984.

*Lanneau, G., Baubion-Broye, A. \& Cassagne, J. (1971). Société villageoise et coopération agricole. Archives Internationales de Sociologie de la Coopération, 26, 24-57. 
*Larsén, K. (2007). Participation, incentives and social norms in partnership arrangements among farms in Sweden. In Annual meeting of the American agricultural economics association (pp. 1-34). Portland, Oregon. July 2007.

*Larsén, K. (2010). Effects of machinery-sharing arrangements on farm efficiency: Evidence from Sweden, Agricultural Economics, 41(5), 497-506.

*Le Guédard, P. (2010). Cadre de référence pour la mise en place et le développement des CUMA et des CUMO. Direction régionale du Bas-Saint-Laurent MAPAQ, Québec.

*Lucas V., Gasselin, P., Thomas F. \& Vaquié, P. (2014). Coopérative agricole de production: Quand l'activité agricole se distribue entre exploitation et action collective de proximité. In P. Gasselin, J.-P. Choisis, S. Petit, F. Purseigle, \& S. Zasser (Eds.), L'agriculture en famille, (pp. 201-222). Paris: EDP Sciences.

*Lucas, V., \& Gasselin, P. (2018). Gagner en autonomie grâce à la Cuma. Expériences d'éleveurs laitiers français à l'ère de la dérégulation et de l'agroécologie. Économie Rurale, 364(2), 73-89.

*Lucas, V., Gasselin, P., \& Van Der Ploeg, J. D. (2019). Local inter-farm cooperation: A hidden potential for the agroecological transition in Northern agricultures. Agroecology and Sustainable Food Systems, 43(2), 145-179.

*McArthur, J. (1980). Machines agricoles et transformations sociales: Accès au matériel agricole en CUMA et organisations agricoles dans deux cantons de Haute-Garonne. Revue Géographique des Pyrénées et du Sud-Ouest, 51(4), 411-439.

McLeod, M. S., Payne, G. T., \& Robert, E. E. (2016). Organizational ethics research: A systematic review of methods and analytical techniques. Journal of Business Ethics, 134(3), 429-443.

Melé, D. (2009). Integrating personalism into virtue-based business ethics: The personalist and the common good principles. Journal of Business Ethics, 88(1), 227-244.

Melé, D. (2012). The firm as a "community of persons": A pillar of humanistic business ethos. Journal of Business Ethics, 106(1), 89-101.

Menzani, T., \& Zamagni, V. (2010). Cooperative networks in the Italian economy. Enterprise \& Society, 11(1), 98-127.

Merrett C. D., \& Waltzer N. (2004). Cooperatives and local development: Theory and applications for the 21st century. New York \& London: M.E. Sharpe.

Meyer, C., \& Hudon, M. (2019). Money and the commons: An investigation of complementary currencies and their ethical implications. Journal of Business Ethics, 160(1), 277-292.

*Morneau, C. (1999). CUMA: Une structure économique. Université rurale québécoise au BasSaint-Laurent, Québec. 
*Norby, J. (1950). Cooperative and contract use of farm machinery in Norway. Journal of Farm Economics, 32(2), 290-299.

* Nouwogou, K. (2016). Promouvoir la mécanisation agricole à travers les coopératives agricoles: Cas de CUMAs au Bénin. In Proceedings of the consultative meeting on mechanization strategy. Nairobi, Kenya. December 2016.

Olmstead, A., \& Rhode, P. (1995). Beyond the threshold: An analysis of the characteristics and behavior of early reaper adopters. Journal of Economic History, 55(1), 27-57.

Ostrom, E. (1990). Governing the commons: The evolution of institutions for collective action. Cambridge: Cambridge University Press.

Ostrom, E. (1995). Understanding institutional diversity. Princeton: Princeton University Press.

Ostrom, E. (2010). Beyond markets and states: Polycentric governance of complex economic systems. American Economic Review, 100(3), 641-672.

Ostrom, E., Walker, J., \& Gardner, R. (1992). Covenants with and without a sword: Selfgovernance is possible. American Political Science Review, 86(2), 404-417.

Ostrom, E., Gardner, R. \& Walker, J. (1994). Rules, games and common-pool resources. Ann Arbor: The University of Michigan Press.

Parris, D. L., \& Peachey, J. W. (2013). A systematic literature review of servant leadership theory in organizational contexts. Journal of Business Ethics, 113(3), 377-393.

Peredo, A. M., \& Chrisman, J. J. (2006). Toward a theory of community-based enterprise. Academy of Management Review, 31(2), 309-328.

Peredo, A. M., \& McLean, M. (online 2019). Decommodification in action: Common property as countermovement. Organization. https://doi.org/10.1177/1350508419867202.

Périlleux, A., \& Nyssens, M. (2017). Understanding cooperative finance as a new common. Annals of Public and Cooperative Economics, 88(2), 155-177.

Persha, L., Agrawal, A., \& Chhatre, A. (2011). Social and ecological synergy: Local rulemaking, forest livelihoods, and biodiversity conservation. Science, 331(6024): 1606-1608.

*Pierre, G. (2009). The biodiesel produced by farmers at a local scale using a traditional procedure: What kind of territorial construction for an agro-environmental project in social economy? European Countryside, 1(3), 141-152.

*Pierre, G. (2013a). L'agriculteur, acteur central des projets d'autonomie agricole, entre choix de vie, choix professionnel et inscription dans des projets collectifs et/ou de territoire. ESO Travaux et Documents, 35, 119-130.

*Pierre, G. (2013b). Produire pour son territoire. De l'autonomie agricole au projet local agroénergétique. Illustrations dans l'ouest français, Unpublished HDR thesis, Université de Caen, Caen. 
*Pierre, G., \& Thareau, B. (2011). Vers de nouveaux rapports au développement agricole au territoire : agir ensemble pour devenir autonome. Revue Internationale de l'Économie Sociale: Recma, 320, 99-115.

Pohler, D., Fairbairn, B., \& Fulton, M. E. (2017). The governance of business federations. Working paper, Centre for the Study of Co-operatives, University of Saskatchewan, Saskatoon.

Polanyi, K. (1944). The great transformation: Economic and political origins of our time. New York: Rinehart.

Poteete, A., Janssen, M., \& Ostrom, E. (2009). Working together: Collective action, the commons, and multiple methods in practice. Princeton: Princeton University Press.

Putterman, L. (1983). A modified collective agriculture in rural growth-with-equity: Reconsidering the private, unimodal solution. World Development, 11(2), 77-100.

Sacchetti, S. (2015). Inclusive and exclusive social preferences: A Deweyan framework to explain governance heterogeneity. Journal of Business Ethics, 126(3), 473-485.

Scalet, S. (2006). Prisoner's dilemmas, cooperative norms, and codes of business ethics. Journal of Business Ethics, 65(4), 309-323.

Schlager, E., \& Ostrom, E. (1992). Property rights regimes and natural resources: A conceptual analysis. Land Economics, 68(3), 249-262.

Shamoo, A. E., \& Resnik, D. B. (2009). Responsible conduct of research. Oxford: Oxford University Press.

Sison, A., Hartman, E., \& Fontrodona, J. (2012). Guest editors' introduction reviving tradition: Virtue and the common good in business and management. Business Ethics Quarterly, 22(2), 207-210.

Schmidtz, D. (2001). A place for cost-benefit analysis. Philosophical Issues, 11(1), 148-171.

Stark, D. (2011). The sense of dissonance: Accounts of worth in economic life. Princeton: Princeton University Press.

Stiglitz, J. (2009). Moving beyond market fundamentalism to a more balanced economy. Annals of Public and Cooperative Economics, 80(3), 345-360.

*Stofferahn, C. (2004). Individualism or cooperation: Preferences for sharing machinery and labor. Journal of Cooperatives, 18, 1-17.

*Takacs, I., \& Takacs-György, G. (2012). Cooperation among farmers for cost saving machinery. In Third International Symposium "Agrarian economy and rural development: Realities and perspectives for Romania (pp. 327-335). Bucharest, Romania. October 2012.

Tang, S. Y. (1992). Institutions and collective action: Self-governance in irrigation. San Francisco: ICS Press. 
*Thomas, F., \& Draperi, J. (2008). Les nouvelles frontières de la coopération d'utilisation de matériels agricoles. In Les entreprises coopératives agricoles: Mutations et perspectives (pp. 1-18). Paris, France. February 2008.

*Thomas, F., Vaquié, P., Lucas, V., \& Gasselin, P. (2015). Coopération agricole de production: Renouvellement des modalités de coopération de proximité entre agriculteurs. In Structures d'exploitation et exercice de l'activité agricole : Continuités, changements ou ruptures ? (pp. 1-11). Rennes, France. February 2015.

USDA (1980). Cooperative benefits and limitations, farmer cooperatives in the United States. Cooperative information report 1 section 3, United-States Department of Agriculture, Washington.

Van der Ploeg, J. D. (2012). The new peasantries: Struggles for autonomy and sustainability in an era of empire and globalization. London and Sterling: Routledge.

*Vasa, L., Baranyai, Z., Kovacs, Z., \& Szabo, G. (2014). Drivers of trust: Some experiences from Hungarian agricultural cooperatives. Journal of International Food \& Agribusiness Marketing, 4(26), 286-297.

Wade, R. (1987). Village republics: Economic conditions for collective action in South India. Cambridge: Cambridge University Press.

*Wolfley, J., Mjelde, J., Klinefelter, D., \& Salin, V. (2011). Machinery-sharing contractual issues and impacts on cash flows of agribusinesses. Journal of Agricultural and Resource Economics, 36(1), 139-159.

Wu, J., Fisher, M., \& Pascual, U. (2011). Urbanization and the viability of local agricultural economies. Land Economics, 87(1), 109-125. 
Table 1: Machinery Sharing Agreements around the World

\begin{tabular}{|c|c|c|c|c|c|}
\hline \multirow[t]{2}{*}{ Country } & \multirow{2}{*}{$\begin{array}{l}\text { Number of } \\
\text { institutions }\end{array}$} & \multirow{2}{*}{$\begin{array}{c}\text { Number of } \\
\text { members, coverage }\end{array}$} & \multirow{2}{*}{$\begin{array}{l}\text { Legal status of the } \\
\text { arrangement }\end{array}$} & \multicolumn{2}{|c|}{ Main source of information } \\
\hline & & & & Academic source & Institutional source \\
\hline \multicolumn{6}{|l|}{ Europe } \\
\hline France & 12,600 CUMAs & $50 \%$ of farmers & Cooperatives & FNCUMA (2019) & CUMA Federation \\
\hline Belgium & 110 CUMAs & & Cooperatives & $\begin{array}{l}\text { Gijselinckx and } \\
\text { Bussels (2012) }\end{array}$ & $\begin{array}{l}\text { Walloon } \\
\text { Agricultural } \\
\text { Federation } \\
\end{array}$ \\
\hline Ireland & $\begin{array}{l}900 \text { dairy farm } \\
\text { partnerships }\end{array}$ & $5 \%$ of dairy farmers & $\begin{array}{l}\text { Co-ownership in } \\
\text { partnerships }\end{array}$ & $\begin{array}{l}\text { Cush and Macken- } \\
\text { Walsh (2016) }\end{array}$ & \\
\hline Austria & $\begin{array}{l}86 \text { machinery } \\
\text { rings }\end{array}$ & $\begin{array}{l}75,300 \text { members, } \\
60 \% \text { of farmers }\end{array}$ & $\begin{array}{l}\text { Machinery ring } \\
\text { associations }\end{array}$ & Abrahamsson (2015) & \\
\hline Germany & $\begin{array}{l}240 \text { local } \\
\text { machinery rings }\end{array}$ & 192,000 members & $\begin{array}{l}\text { Machinery ring } \\
\text { associations }\end{array}$ & Abrahamsson (2015) & $\begin{array}{l}\text { Mashinenring } \\
\text { Deutschland }\end{array}$ \\
\hline England/Wales & $\begin{array}{l}11 \text { machinery } \\
\text { rings }\end{array}$ & & $\begin{array}{l}\text { Machinery ring } \\
\text { associations }\end{array}$ & $\begin{array}{l}\text { Artz and Naeve } \\
(2016)\end{array}$ & $\begin{array}{l}\text { Machinery Ring } \\
\text { Association of } \\
\text { England and Wales }\end{array}$ \\
\hline Scotland & $\begin{array}{l}10 \text { machinery } \\
\text { rings }\end{array}$ & $\begin{array}{l}7,000 \text { members, } \\
23 \% \text { of farmers }\end{array}$ & $\begin{array}{l}\text { Machinery ring } \\
\text { associations }\end{array}$ & $\begin{array}{l}\text { Flanigan and } \\
\text { Sutherland (2016) }\end{array}$ & $\begin{array}{l}\text { Scottish Machinery } \\
\text { Ring } \\
\text { Association (2017) }\end{array}$ \\
\hline Spain & $\begin{array}{l}\text { Some in the } \\
\text { Basque Country, } \\
\text { Navarra, Galicia }\end{array}$ & & Cooperatives & $\begin{array}{l}\text { Giagnocavo and } \\
\text { Vargas-Vasserot } \\
(2012) \text {. }\end{array}$ & \\
\hline Norway & & $25 \%$ of dairy farms & $\begin{array}{l}\text { Co-ownership in } \\
\text { partnerships }\end{array}$ & Almås (2010) & \\
\hline Sweden & $\begin{array}{l}20 \text { machinery } \\
\text { ring associations }\end{array}$ & $\begin{array}{l}5,000 \text { members, } 60- \\
80 \% \text { of farms }\end{array}$ & $\begin{array}{l}\text { Machinery ring } \\
\text { associations and } \\
\text { various types of } \\
\text { partnerships }\end{array}$ & $\begin{array}{l}\text { De Toro and } \\
\text { Hansson (2004) }\end{array}$ & \\
\hline \multicolumn{6}{|l|}{ America } \\
\hline United States & Unknown & & $\begin{array}{l}\text { Various types of } \\
\text { partnerships }\end{array}$ & Artz et al. (2010) & \\
\hline $\begin{array}{l}\text { Canada } \\
\text { (Quebec) }\end{array}$ & 60 CUMAs & $\begin{array}{l}1,917 \text { members } \\
(2015), 7 \% \text { of } \\
\text { farmers }\end{array}$ & Cooperatives & $\begin{array}{l}\text { Harris and Fulton } \\
(2000 a)\end{array}$ & $\begin{array}{l}\text { CUMA Canada } \\
\text { Association (2015) }\end{array}$ \\
\hline \multicolumn{6}{|l|}{ Africa } \\
\hline Benin & 115-132 CUMAs & 1,250 members & Cooperatives & Nouwogou (2016) & $\begin{array}{l}\text { Union Régionale des } \\
\text { CUMA de Borgou } \\
\text { Alibori }\end{array}$ \\
\hline
\end{tabular}


Table 2: CPAs among Farm Machinery Arrangements

\begin{tabular}{|lcc|cc|c|}
\hline & Mutual aid & $\begin{array}{c}\text { Machinery } \\
\text { rings }\end{array}$ & $\begin{array}{c}\text { Machinery } \\
\text { partnerships }\end{array}$ & $\begin{array}{c}\text { Machine } \\
\text { cooperatives, } \\
\text { CUMAs }\end{array}$ & $\begin{array}{c}\text { Individual } \\
\text { ownership }\end{array}$ \\
\hline Access right & $\mathrm{X}$ & $\mathrm{X}$ & $\mathrm{X}$ & $\mathrm{X}$ & $\mathrm{X}$ \\
\hline Withdrawal right & $\mathrm{X}$ & $\mathrm{X}$ & $\mathrm{X}$ & $\mathrm{X}$ & $\mathrm{X}$ \\
\hline Management right & & & $\mathrm{X}$ & $\mathrm{X}$ & $\mathrm{X}$ \\
\hline Exclusion right & & $\mathrm{X}$ & $\mathrm{X}$ & $\mathrm{X}$ \\
\hline Alienation right & & \multicolumn{2}{|l}{} & $\mathrm{X}$ \\
\hline
\end{tabular}

Table 3: Descriptive Characteristics of the Sample

\begin{tabular}{|c|c|c|c|}
\hline Category & Classification & $\mathbf{N}$ & $\%$ \\
\hline \multirow[t]{4}{*}{ Type of material } & Case studies & 30 & $56 \%$ \\
\hline & Technical reports & 12 & $22 \%$ \\
\hline & Conceptual papers & 12 & $22 \%$ \\
\hline & Total & 54 & $100 \%$ \\
\hline \multirow[t]{4}{*}{ Location } & $\begin{array}{l}\text { Europe } \\
\text { including France }\end{array}$ & $\begin{array}{l}37 \\
24\end{array}$ & $\begin{array}{l}68 \% \\
44 \%\end{array}$ \\
\hline & America & 16 & $30 \%$ \\
\hline & Africa & 1 & $2 \%$ \\
\hline & Total & 54 & $100 \%$ \\
\hline \multirow[t]{4}{*}{ Methods used } & Qualitative & 34 & $63 \%$ \\
\hline & Quantitative & 11 & $20 \%$ \\
\hline & Qualitative \& quantitative & 9 & $17 \%$ \\
\hline & Total & 54 & $100 \%$ \\
\hline \multirow{2}{*}{$\begin{array}{l}\text { Main types of machinery sharing } \\
\text { CPA agreements discussed in the } \\
\text { sample* }\end{array}$} & Machinery cooperatives & 38 & $70 \%$ \\
\hline & Machinery partnerships & 21 & $39 \%$ \\
\hline \multirow{3}{*}{$\begin{array}{l}\text { Main types of impact observed or } \\
\text { discussed* }\end{array}$} & Economic, financial, monetary & 44 & $81 \%$ \\
\hline & Social & 36 & $67 \%$ \\
\hline & Agro-environmental & 10 & $18 \%$ \\
\hline
\end{tabular}

*Total $>100 \%$ because all appropriate classifications can be selected for a given document.

Table 4: Quality Assessment Attributes of the Sample

\begin{tabular}{|c|c|c|c|}
\hline & $\begin{array}{c}\text { Independent } \\
\text { affiliation }\end{array}$ & Close affiliation & Total \\
\hline Peer-reviewed source & $28(52 \%)$ & $3(5 \%)$ & $23(43 \%)$ \\
\hline $\begin{array}{c}\text { Source's peer-review } \\
\text { status uncertain or non- } \\
\text { existent }\end{array}$ & $19(35 \%)$ & $4(8 \%)$ & $54(100 \%)$ \\
\hline Total & $47(87 \%)$ & $7(13 \%)$ & \\
\hline
\end{tabular}


Table 5: Costs and Benefits from Participating in a Farm Machinery CPA

\begin{tabular}{|c|c|c|c|}
\hline & & $\%$ & Observations \\
\hline \multirow[t]{3}{*}{$\begin{array}{c}\text { Direct } \\
\text { benefits }\end{array}$} & Costs reduction & 98 & $\begin{array}{l}\text { - } 14 \% \text { to } 70 \% \text { lower mechanisation costs compared to individual ownership (Harris and Fulton } 2000 \mathrm{a} \text {; Kenkel and Long } 2007 \mathrm{a} \text { ). } \\
\text { - Operating costs and annual fixed costs are } 14 \% \text { and } 45 \% \text { lower, respectively, for an individual farmer when joining a cooperative with two other } \\
\text { farmers exhibiting the same characteristics (Harris and Fulton } 2000 \mathrm{~b} \text { ). } \\
\text { - Decrease in total costs by about } 15 \% \text { (De Toro and Hansson 2004). }\end{array}$ \\
\hline & Productivity increase & 87 & $\begin{array}{l}\text { - Internal economies of scale reflect the ability to use specialised, modern, improved equipment to gain efficiency with a lower capital cost (Baranyai } \\
\text { et al. 2014). Acquisition of more advanced technology for a similar cost (Larsén 2007). }\end{array}$ \\
\hline & Profit increase & 63 & - $55 \%$ to $85 \%$ of gross farm income (Andersson et al. 2005). \\
\hline \multirow{7}{*}{$\begin{array}{l}\text { Indirect } \\
\text { benefits }\end{array}$} & 'Learning by doing' & 72 & - The 'learning by doing' process enables farmers to share experience (Artz and Naeve 2016; Harris and Fulton 2000b). \\
\hline & $\begin{array}{l}\text { Diffusion of innovation } \\
\quad \& \text { improvement of } \\
\text { working environment }\end{array}$ & 80 & $\begin{array}{l}\text { - The risk associated with trying new techniques is collectively borne (Herbel et al. 2015; Larsén 2007). } \\
\text { - In France, prompted by the Ministry of Agriculture's modernisation policy after World War II, CUMAs became a popular meeting space for young } \\
\text { farmers in search of innovations (Barthélémy de Saizieu 1984; Cocaud 2001). } \\
\text { - Cooperation can induce a shift towards environmentally friendly practices (Chalopin and Masson 1999; Lucas et al. 2014; Pierre 2009). }\end{array}$ \\
\hline & $\begin{array}{l}\text { Access to reliable skilled } \\
\text { labour }\end{array}$ & 68 & $\begin{array}{l}\text { - Labour force can be hard to find (Artz et al. 2010) and is viewed as more reliable when working year-round for the same group of farmers, thus } \\
\text { decreasing moral hazard costs. } \\
\text { - In the case of labour shortage, internalising the labour exchange with machinery among neighbouring farmers avoids major transaction costs } \\
\text { (Lanneau 1969). }\end{array}$ \\
\hline & $\begin{array}{l}\text { Improvement of farmers' } \\
\text { bargaining power }\end{array}$ & 22 & $\begin{array}{l}\text { - CPAs coordinate the marketing of products and the purchase of production factors to get cheaper, wider access to operating inputs (such as seeds } \\
\text { and fertilisers) and negotiating services (Larsén 2010). }\end{array}$ \\
\hline & 'Stimulus effect' & 22 & - Intensity of effort is greater when individuals work together on a task rather than on their own (Almås 2010; De Toro and Hansson 2004). \\
\hline & Risk reduction & 59 & $\begin{array}{l}\text { - Farmers minimise their exposure to investment risk by shifting it among all the cooperative's members. The risk is also reduced in the case of } \\
\text { decreasing working capacity in a farm (De Toro and Hansson 2004). In some cooperatives, mutualisation can result in financial compensation for } \\
\text { members who incur losses caused by timeliness delays (Capitaine 2005). }\end{array}$ \\
\hline & Fostering mutual aid & 57 & $\begin{array}{l}\text { - In the case of decreased working capacity on a farm (e.g. due to illness), the affected farmer experiences less vulnerability because farmers can } \\
\text { replace one another within the institution (Almås 2010; De Toro and Hansson 2004). }\end{array}$ \\
\hline $\begin{array}{l}\text { Direct } \\
\text { costs }\end{array}$ & $\begin{array}{l}\text { Timeliness and } \\
\text { coordination costs }\end{array}$ & 80 & $\begin{array}{l}\text { - Explicit timeliness costs typically comprise the cost of transporting equipment from one farm to another (Artz and Naeve 2016). } \\
\text { - Implicit costs are incurred by scheduling issues, in other words when the machinery is not available exactly when needed (Norby 1950). } \\
\text { - } 22 \% \text { of Turkish agricultural chambers offering farm machinery sharing services still encounter difficulties in schedule planning, and } 15 \% \text { are } \\
\text { affected by late returns (Basarik and Yildirim 2015). }\end{array}$ \\
\hline $\begin{array}{l}\text { Indirect } \\
\text { Costs }\end{array}$ & Collective action costs & 39 & $\begin{array}{l}\text { - Moral hazard problems arise from the fact that it is impossible for a CPA member to ensure-without incurring a high monitoring cost-that his } \\
\text { or her fellow members use the machinery carefully. } \\
\text { - Opportunistic behaviours typically occur when farmers use common assets in an irresponsible manner and do not bear the full costs of their actions } \\
\text { (Basarik and Yildirim 2015; Takacs and Takacs-György 2012). }\end{array}$ \\
\hline
\end{tabular}

Note: the \% column shows the prevalence of each benefit/cost item in the studies reviewed (see Table B1 in Appendix B). 
Table 6: Institutional Design Principles in Farm Machinery CPAs

\begin{tabular}{|c|c|c|c|}
\hline Key principles & $\mathbf{P}$ & $\%$ & Observations \\
\hline $\begin{array}{l}\text { Clearly defined } \\
\text { user \& resource } \\
\text { boundaries }(\mathrm{O} 1)\end{array}$ & $\begin{array}{l}\text { P1 } \\
\& \\
\text { P2 }\end{array}$ & 93 & $\begin{array}{l}\text { - In CPAs with a legal status, any individual signing the formal agreement belongs to the group. Boundaries are blurred for informal arrangements (Cush and Macken- } \\
\text { Walsh 2016). The shared resource is well defined whether the arrangement is formal or informal, as a result of its human-made attribute. }\end{array}$ \\
\hline $\begin{array}{l}\text { Locally devised } \\
\text { access and } \\
\text { management } \\
\text { rules with } \\
\text { benefits } \\
\text { proportional to } \\
\text { the amount of } \\
\text { input required } \\
(\mathrm{O} 2)\end{array}$ & P2 & 65 & $\begin{array}{l}\text { - The democratic 'one member, one vote' rule is particularly prevalent in the French CUMAs. } \\
\text { - The choice of allocation strategy, while it may not necessarily be the best one in terms of economic efficiency, tries to maximise the sense of fairness among the CPA } \\
\text { members and rewards members in proportion to their level of involvement. } \\
\text { Timeliness of operations is found to be the main issue for the CPAs in this study because it increases decision-making costs and fuels interpersonal tensions (Artz et al. } \\
\text { 2010; Capitaine 2005; Edwards 2013). } \\
\text { Various strategies are adopted to cope with the timeliness issue while ensuring fairness among members, including an identical time of use of the equipment for every } \\
\text { member, a circular planting scheme where the starting point rotates on an annual basis, and a randomly decided order of machinery use. Natural, exogenous variables } \\
\text { (e.g. nature of the soil) may also be used to decide the sequencing of machinery use so that the schedule appears more objective, neutral, and acceptable to CPA } \\
\text { members (Artz et al. 2010). }\end{array}$ \\
\hline $\begin{array}{l}\text { Collective- } \\
\text { choice } \\
\text { arrangements } \\
\text { (O3) }\end{array}$ & P2 & 72 & $\begin{array}{l}\text { - Rules are generally consensually adopted, but this becomes more difficult as group size increases. } \\
\text { - Members in each machinery sharing group elaborate their own set of formal and informal rules regarding operating conditions (Artz et al. 2010). } \\
\text { - Small groups mainly use verbal agreements, whereas groups operating on a larger scale have at least one written agreement in place (Artz et al. 2010; Hofstrand 2000). } \\
\text { - Groups do not necessarily have a formal decision-making process. In small groups, frequent face-to-face communication is the usual way to make decisions (Artz and } \\
\text { Naeve 2016). }\end{array}$ \\
\hline $\begin{array}{l}\text { Resource and } \\
\text { user monitoring. } \\
\text { Monitors } \\
\text { accountable to } \\
\text { users (O4) }\end{array}$ & $\mathrm{P} 2$ & 35 & $\begin{array}{l}\text { - To reduce the time spent on meetings (and the associated opportunity costs), information-gathering may be delegated to specific members, who then report back to the } \\
\text { whole group (Artz et al. 2010). } \\
\text { - In CPAs, there is generally one member (designated by the group) who is accountable for each piece of equipment. This member is vested with the legitimacy and } \\
\text { authority to organise the schedules and ensure the equipment is well-maintained and stored in an appropriate place. This member also determines whether any damage } \\
\text { is due to negligence or obsolescence (Harris and Fulton 2000a; Lanneau 1969; Le Guédard 2010). Peer-pressure forms a second layer of social control against } \\
\text { opportunistic behaviours. }\end{array}$ \\
\hline $\begin{array}{l}\text { Graduated } \\
\text { sanctions (O5) }\end{array}$ & $\mathrm{P} 2$ & 9 & $\begin{array}{l}\text { - Case studies barely mention this design principle. } \\
\text { - In formal agreements, the bylaws sometimes include guidelines on sanctions, such as financial penalties or the repair of damaged equipment (Capitaine 2005; Herbel } \\
\text { et al. 2015). } \\
\text { - In theory, members should be excluded in cases of serious misconduct, but none of the documents analysed here reports such an extreme sanction. }\end{array}$ \\
\hline $\begin{array}{l}\text { Conflict- } \\
\text { resolution } \\
\text { mechanisms } \\
\text { (O6) }\end{array}$ & P2 & 48 & $\begin{array}{l}\text { - Light violation: informal conflict resolution is often encouraged to avoid resorting to bylaws and the creation of tensions among group members (Barthélémy de Saizieu } \\
\text { 1984). } \\
\text { Regular meetings give members the opportunity to discuss problems as long as they can still be easily solved with direct communication (Artz et al. 2010; Capitaine } \\
\text { 2005; Harris and Fulton } 2000 \text { c). }\end{array}$ \\
\hline $\begin{array}{l}\text { Minimal } \\
\text { Recognition of } \\
\text { Rights to } \\
\text { Organise (O7) }\end{array}$ & $\begin{array}{l}\text { P1 } \\
\& \\
\text { P2 }\end{array}$ & 80 & $\begin{array}{l}\text { - Although informal cooperative farming arrangements may exist, formal cooperation can only exist in especially favourable conditions with supportive institutions and } \\
\text { enabling legislation (Stofferahn 2004). } \\
\text { - In France, at State level, the government has supported the CUMA movement through legislation since World War II. At regional level, local government often makes } \\
\text { use of local CUMA services on a daily basis in rural areas. }\end{array}$ \\
\hline
\end{tabular}

Note: the \% column shows the prevalence of each principle in the studies reviewed (see Table B2 in Appendix B). 


\section{Table 7: Membership Attributes in Farm Machinery CPAs}

\begin{tabular}{|c|c|c|c|}
\hline Critical attributes & $\mathbf{P}$ & $\%$ & Observations \\
\hline $\begin{array}{l}\text { Small group size } \\
\text { (G1) }\end{array}$ & $\begin{array}{l}\text { P1 } \\
\& \\
\text { P2 }\end{array}$ & 55 & $\begin{array}{l}\text { - Farmers work better in smaller rather than larger groups (all studies with only a few exceptions). } \\
\text { - Small group size ensures interpersonal knowledge, limits information asymmetries among members, fosters flexibility, and curtails drop-out (Barthélémy de Saizieu } \\
\text { 1984; Cush and Macken-Walsh 2016; Harris and Fulton 2000a; Herbel et al. 2015; Lanneau 1969). }\end{array}$ \\
\hline \multirow{2}{*}{$\begin{array}{l}\text { Successful past } \\
\text { experience of } \\
\text { collective action } \\
\text { (G2) }\end{array}$} & P1 & 50 & $\begin{array}{l}\text { - Most farmers involved in a CPA draw on their past experience of machinery sharing arrangements, cooperative practices (Artz and Naeve 2016; FWA 2012; Harris } \\
\text { and Fulton 2000a, 2000c; Stofferahn 2004; Thomas et al. 2015), and neighbour assistance (Beaudry et al. 2002; Lanneau 1969). }\end{array}$ \\
\hline & P2 & 44 & $\begin{array}{l}\text { - When farmers strengthen cooperation, they prioritise, as an indicator of trust and 'like-mindedness', the farmers they enjoy working with most (Gröger 1981) or } \\
\text { have known the longest (Jannot and Vaquié 1997). }\end{array}$ \\
\hline \multirow[t]{2}{*}{$\begin{array}{l}\text { Appropriate } \\
\text { leadership (G3) }\end{array}$} & $\mathrm{P} 1$ & 44 & $\begin{array}{l}\text { - Young, socially well-integrated, charismatic and trustworthy leaders who cooperate with friends are needed to initiate the project. Leaders are less chiefs and more } \\
\text { conciliators (Artz and Naeve 2016; Capitaine 2005; Le Guédard 2010). }\end{array}$ \\
\hline & P2 & 43 & $\begin{array}{l}\text { - Leaders must be vested with the legitimacy to lead the group (Takacs and Takacs-György 2012). } \\
\text { - Leaders must be willing to lead the project (Barthélémy de Saizieu 1984; Jannot and Vaquié 1997; Norby 1950). } \\
\text { - Leaders must be in touch with all stakeholders, namely farmers, local government representatives, agricultural advisers, institutional networks, and the community } \\
\text { (McArthur 1980; Pierre 2013a). }\end{array}$ \\
\hline $\begin{array}{l}\text { Interdependence } \\
\text { among group } \\
\text { members (G4) }\end{array}$ & P2 & 80 & $\begin{array}{l}\text { - If individual farmers are heavily dependent on their own working abilities to perform field operations on time, they can replace one another and fill gaps in order to } \\
\text { avoid prejudicing the entire group (Artz and Naeve 2016; Beaudry et al. 2002; De Toro and Hansson 2004). } \\
\text { - Farmers specialising according to their preferences and skills not only improve labour productivity by coordinating tasks and reducing duplication but also enhance } \\
\text { group cohesion (Capitaine 2005; Gertler 1981; Kenkel and Long 2007b; Lanneau et al. 1971). } \\
\text { - Routines help keep coordination costs low in cases of interdependence (Capitaine 2005; Capitaine et al. 2008). }\end{array}$ \\
\hline \multirow[t]{2}{*}{$\begin{array}{l}\text { Shared norms, } \\
\text { homogeneity of } \\
\text { identities and } \\
\text { interests (G5) }\end{array}$} & $\mathrm{P} 1$ & 69 & $\begin{array}{l}\text { - The existence of common values (such as flexibility and fairness) and a willingness to put the group's wellbeing before individual interests also supports the } \\
\text { development of essential group-level social capital (Jeanneaux et al. 2018). } \\
\text { - Cooperative practices are difficult to implement in post-communist Eastern European countries (Takacs and Takacs-György 2012). } \\
\text { - A group should be initiated by 'like-minded' farmers with a common interest (Cocaud 2001; Harris and Fulton 2000a; Herbel et al. 2015). } \\
\text { - Members tend to cooperate with peers who have similar farming activities and farm sizes (Barthélémy de Saizieu 1984; Herbel et al. 2015). }\end{array}$ \\
\hline & P2 & 67 & $\begin{array}{l}\text { - Similar farming practices and habits regarding machinery care, maintenance, work ethic, and personality (Cropp and Ford 2002). } \\
\text { - Heterogeneity in member age does not adversely affect cooperation (Artz and al. 2010). } \\
\text { - Group farming has also been a major tool in changing French farmers' social representations of (the modernisation of) agriculture since World War II (Barthélémy } \\
\text { de Saizieu 1984; Cocaud 2001). } \\
\text { - Cooperation is often acknowledged as a necessary prerequisite for ensuring farmers' autonomy (e.g. Cush and Macken-Walsh 2016) fostering the individuality of } \\
\text { the most vulnerable and preserving the existence of small farmers in the communities (Almås 2010; Barthélémy de Saizieu 1984; Gröger 1981). } \\
\text { - Cooperation can induce a shift towards environmentally friendly practices (Chalopin and Masson 1999; Lucas et al. 2019; Pierre 2013b). }\end{array}$ \\
\hline
\end{tabular}

Note: the \% column shows the prevalence of each attribute in the studies reviewed (see Table B2 in Appendix B) 
Figure 1: Methodological Approach

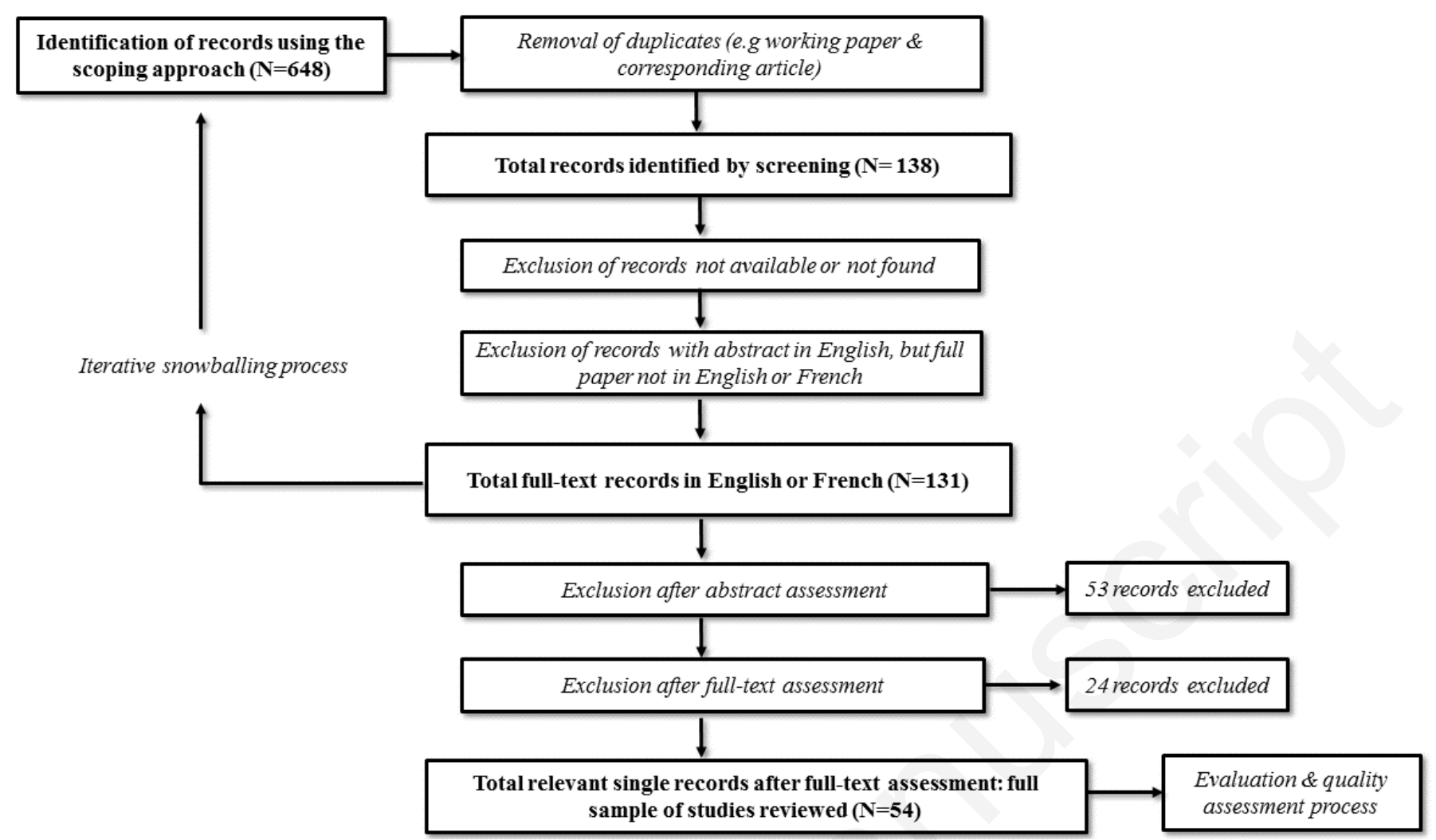

